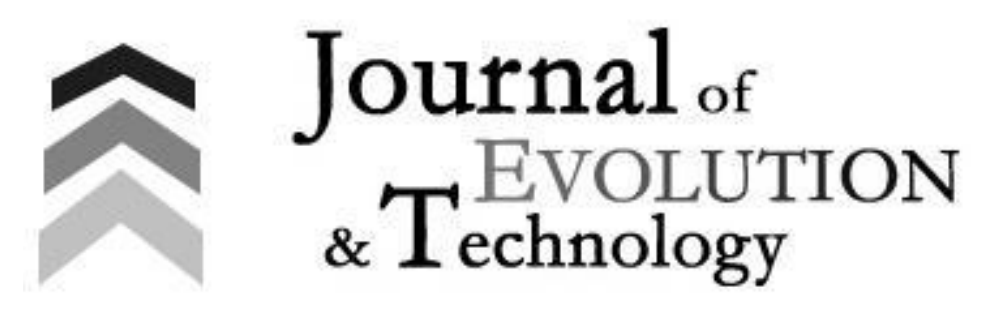

A peer-reviewed electronic journal published by the Institute for Ethics

Emerging Technologies

ISSN 1541-0099

20(2) - December 2009

\title{
Book review: David Koepsell's Who Owns You?: The Corporate Gold-Rush to Patent Your Genes
}

\author{
Randall Mayes \\ Science \& Technology Writer/ Policy Analyst \\ randy.mayes@duke.edu \\ Journal of Evolution and Technology - Vol. 20 Issue 2 - December 2009 - pgs 80-85 \\ $\mathrm{http} / / /$ jetpress.org/v20/mayes.htm
}

Who Owns You: The Corporate Gold-Rush to Patent Your Genes. David Koepsell. WileyBlackwell, Hoboken, NJ. 2009. 200 pp., $\$ 75.00$ hardback

ISBN: $140518731 \mathrm{X}$

Pasteur patented a form of yeast for making beer in 1873, and scientists received patents for hybrid plants in the early 1900s. In the 1980s, however, patents issued on drugs derived from genetically engineered human proteins and genetically modified bacteria intended to break down oil brought activists out of the woodwork. Bioconservatives challenged the patents for moral reasons and liberals for economic reasons based on their own system of values.

With the more recent ability to sequence genomes and the subsequent increase in gene patents, opposition has once again resurfaced. This year the ACLU, representing a number of clients, is challenging the constitutionality of patents on two breast cancer genes and the proprietary licensing of a diagnostic test to detect the presence of these genes.

In Who Owns You?: The Corporate Gold-Rush to Patent Your Genes, David Koepsell, trained as a lawyer and philosopher, approaches the topic of gene patents by discussing the science of DNA, the philosophical ramifications for personhood, and the allegedly negative impact on research and subsequent discoveries. However, Koepsell has chosen a book title that I find as controversial as the topic itself. He attempts to engage the public by pressing two hot buttons, gene ownership and corporate greed. Based on his discussions of these topics, he attacks the current biotechnology infrastructure and develops ethical, legal, and economic arguments for a commons by necessity for human genes. 
To discuss the first hot button of gene ownership and perceived issues relating to personhood relating to patenting genes, it is first necessary to consider the basics of patenting DNA. Koepsell does a commendable job of explaining two essential and complex concepts: what patenting a gene actually means; and what is actually patented. This is the major strength of the book. Koepsell states that patents cover the DNA molecule, which is casual information, not the nucleotides (ACGT) or genetic code which are semantic information (compare Wilson 2002). He accurately states that the Thirteenth Amendment which prohibits slavery also prevents the ownership of human DNA in the United States.

Koepsell's discussion should take the fight out of any critic's moral argument against patenting genes. Yet it is unclear why the author chooses to repeat the concept of ownership of genes throughout the book, as well as the title. If the reader is not knowledgeable about patent law and misses several sentences which accurately state that patents are not a possessory right, together with the reference to the Thirteenth Amendment, they may actually believe patent holders own genes, rather than owning a patent. The latter is, of course, totally different. This is the first weakness of the book. The concept would be less confusing to the reader had the repeated use of "owning genes" been more rigorously and consistently qualified throughout. Koepsell is well aware of this issue, and he concedes nobody actually owns genes. Why, then, insist on such misleading and tendentious language?

To press the second hot button in the title, corporate greed, Koepsell credits Craig Venter as leading "The Corporate Gold-Rush to Patent Your Genes," and the mere mention of Venter's name is guaranteed to rally critics of patenting genes. But in reality, a number of companies patented genes decades earlier than Venter. In developing this theme of profit and greed, Koepsell claims that legal errors were made by the courts in allowing gene patents. He calls for "reasoned introspection," since he believes the American federal government failed to provide adequate public discussions. This argument assumes that public input is crucial for public decision making on the legality of gene patents.

Compare the situation that arose in 1976: when confronted by the novel and misunderstood field of genetic engineering, scientists in the field organized the Asilomar Conference to discuss the future direction for their research. This meeting engaged the public through education and addressed public perceptions, but did no involve the public decision making in the highly specialized field. Today, genetic engineering remains harmless, and Asilomar is a successful paradigm for evaluating the consequences of emerging technologies.

In contrast, lawmakers in the United States turned to the Bill of Rights for guidance on the future direction of patenting DNA. The Bill of Rights clearly outlines individual rights; however, it has no references to the collective good or common ownership of public resources. Since the Constitution says so little about the collective good, some public policy issues are left to the three branches of government to resolve.

However, the U.S. founding fathers clearly promoted patents to provide economic benefits to inventors and to provide products that can increase the quality of citizens' lives. In 1793, Thomas Jefferson drafted a statute, Article I, Section 8 of the U.S. Constitution, giving general guidelines about what is patentable. It provides that Congress has the power to promote the progress of science and useful arts by securing for a limited time to authors and inventors the exclusive right to their respective writings and discoveries. Patents can be obtained for any new or useful art (replaced with process in 1952), machine, manufacture, or composition of matter, or any new or useful improvement thereof. Thus the Constitution clearly favors intellectual property rights where these produce innovations that are of value to the public. 
If you were an American taxpayer in the late 1980s and 1990s, you helped pay for the sequencing of the human genome. In 1988, James Watson justified the hefty $\$ 3$ billion price tag by convincing Congress that the project had the potential to advance medical treatments and provide a tremendous boost to the biotechnology and pharmaceutical industries. In Origins of the Human Genome Project, Robert Cook-Deegan, a Duke University professor, outspoken critic of gene patenting, and proponent of a commons in genetic information, wrote:

Science administrators and members of Congress who shepherded the budgets for genome research (and their counterparts in other nations and international organizations) supported the project not only because of its medical benefits, but also because they saw it as a vehicle for technological advance and creation of jobs and wealth. The main policy rationale for genome research was the pursuit of gene maps as scientific tools to conquer disease, but economic development was an explicit, if subsidiary, goal. (Cook-Deegan 1994.)

While Venter and other biotech companies have legally patented genes, they are not alone. Educational institutions and hospitals, and even the United States government have patented genes without obtaining informed consent. In several cases, and in the resulting discussions of their implications, issues narrowly related to patenting genes became a secondary issue compared to a greater awareness of the need for informed consent and how informed consent legislation varies from state to state.

Koepsell rightly gives attention to the case of Moore v. Regents of the University of California, where Moore sought a share of the royalties from a cell line created from his tissue. He argued that his physician had failed to disclose his economic interests in the donated tissue. In 1990, the Supreme Court of California recognized Moore's right to informed consent, but denied his claims to any property rights in the cell line. So, Moore had no rights to any profits. Koepsell also discusses Greenberg v. Miami Children's Hospital Research Institute (2003), where the Florida district court dismissed an informed consent claim, ruling that research subjects should not dictate how medical research progresses.

Notably absent from Koepsell's book, however, is the inconvenient truth about government greed, notably the Clinton Administration's actions that led to the demise of the Human Genome Diversity Project (HGDP).

In 1991, a group of scientists led by Luca Cavalli-Sforza of Stanford University collected DNA samples from around the world to obtain a representative database of human genetic diversity. Ron Brown, Clinton's Secretary of Commerce filed a patent claim on a cell line from a twentysix year old Guyami woman from Panama. She had a unique virus that made her antibodies useful in AIDS and leukemia research. Despite objections from activists that the DNA samples were collected without consent of the appropriate parties to use their DNA for commercial purposes, the United States Patent and Trademark Office granted the patent. In responding to objections, Brown declared that, under American law, what is patentable is not dependent on the source of the cells. Further protests by a number of groups, including the Guyami people, advocates for indigenous populations including the NGO Rural Advancement Foundation International (RAFI; now known as ETC Group), and the World Council of Indigenous Peoples (WCIP), led to the withdrawal of the patent claim (Whelan 2006).

The Department of Commerce filed for a second patent on a cell line from a native of the Solomon Islands, also for use in potential vaccines or diagnostic tools relating to viruses. After 
protests from the Solomon Islands government, the DOC withdrew the application. Then in 1993, the US Department of Health and Human Services and the National Institutes of Health filed for a patent on a virus found in the Hagahai people in Papua New Guinea, hoping to develop a vaccine for a specific type of leukemia. The Hagahai patent produced little financial reward, so this application was also withdrawn (Whelan 2006).

Debra Harry, an activist and member of an advocacy group called The Indigenous Peoples Council on Biocolonialism, then called for a boycott of the HGDP. The strong and persistent opposition that Luca Cavalli-Sforza and his colleagues received from such groups led to the program's demise. A 1997 National Academy of Sciences report recommended that the National Science Foundation and the NIH no longer fund the HGDP.

By selectively choosing the facts, Koepsell presents an unfair argument for the prevalence of corporate greed. This may persuade readers who are unfamiliar with the full story, but it can only undermine the book's credibility for those who are more knowledgeable in the field. They will, rightly, see the book as portraying an incomplete and unrealistic picture. This is the second weakness of Who Owns You?

Koepsell uses the strategy of placing the current biotechnology infrastructure on trial, rather than providing an example where the concept of a genetic commons has achieved success or adequately demonstrated its economic effectiveness. This is the third weakness in his case. Despite Koepsell's argument, a number of developed countries allow the private sector to patent genes as a means to the end of increased quality of life through wealth creation, cures for diseases, and useful products. Western Europe, Japan, and the United States which have the world's major patent offices also have high standards of living and are the leaders in invention and production of medical and high tech products, partly due to their permissive intellectual property regimes.

Historically, useful products were frequently not developed in the absence of incentives - so society could not receive the benefits. For example, Scottish bacteriologist Alexander Fleming accidentally discovered penicillin in 1928 after leaving a Petri dish of Staphylococcus bacterial culture uncovered for several days and later found it covered with mold. Fleming then discovered the mold was dissolving all the bacteria surrounding it. However, he did not file for a patent or pursue drug development. The antibacterial properties produced by molds in penicillin did not become commercially available until 1941, after the U.S. government sponsored research for mass production. Subsequently, penicillin was used to treat infections on wounded soldiers during World War II.

Scientists have an incentive not to share with others because of the free-rider problem: other parties can benefit from an invention although they did not share the costs of product development. When inventions are underutilized because public goods or services are not developed, a government failure occurs. Situations that lead to government failures require government regulations to correct the situation. Patents provide an economic incentive to commercialize products and ensure they are made available to the public rather than developing trade secrets or not pursuing them.

Following the Cold War, a shift to applied research took place which led to biotech hubs that included Boston and Silicon Valley. This, in turn, led to increased patent protection and favorable rulings by the courts. At the end of the 1970s, federal agencies in the United States held roughly 28,000 patents; according to Lila Feisee of the Biotechnology Industry Association, however, 
they had licensed fewer than 5 percent of them. Consequently, citizens were not receiving benefits - a government failure.

Because of a lack of incentives to create useful products, the U.S. government developed the current infrastructure that brought activists out of the woodwork in the 1980s. Government intervention through the Federal Transfer Technology Act (1986) mandated the transfer of federal biotechnology research to the private sector and the Bayh-Dole Act (1980) required researchers receiving federal funding to patent and commercialize important discoveries. Part of the public sector's role is to reduce barriers that cause private companies to fail. In addition, the government provides funding for research and tax incentives to create start up companies so citizens will receive social benefits.

Because of the interdisciplinary nature of discussions that relate to the merits of patenting DNA, together with the specialized nature of patent law, it is a rare individual, whether author, reader, or reviewer, who is expert in all the disciplines that have provided input to the current biotechnology infrastructure. Unfortunately, Koepsell's book is not a resource to evaluate both sides of the complex gene patenting issue; rather, it advocates the case for one controversial position, and does so in a one-sided way.

Because the topic caters to a relatively small audience, this book is part of Wiley-Blackwell's public philosophy series, which engages the public with discussions of topics of public importance. Does the book succeed in this aim? The only other review of the book that I have seen is by Chris Holman (Holman 2009), a patent attorney with a doctorate in biochemistry and molecular biology. His review pointed out Koepsell's errors in patent law. In response, Koepsell dismissed Holman as unqualified to review his book, since he did not have advanced training in metaphysics (Koepsell 2009). Surely this act is counter to the intentions of the publisher. Unfortunately, it appears that Koepsell will accept no one as properly qualified to review his work unless they possess qualifications similar to his own.

Some activists, including Koepsell, remain determined to take on the tremendous task of challenging, and ultimately overturning, the current intellectual property infrastructure that supports the biotechnology industry. This leads me to the book's fourth weakness: I concur with Holman that Koepsell's arguments have what might be called a pastiche factor, and that the book was published a decade too late. All of the arguments presented were argued ad nauseam by previous activists without success in influencing public policy, and Koepsell has little to add that is genuinely new.

Despite all the activists' arguments, including Koepsell's, it remains unclear how preventing pharmaceutical and biotech companies from seeking profits will speed up the search for cures to diseases. Since the release of Koepsell's book, advocates of the genetic commons idea have suffered another blow. In Prometheus v. Mayo (2009), the U.S. Court of Appeals for the Federal Circuit unanimously reversed a district court's ruling and consequently protected the intellectual property of a diagnostic test for metabolites; this test is important in personalized medicine, and the case sets an important legal precedent.

While activists including Koepsell argue against gene patenting, other scholars and activists have taken another route. They are more solution oriented, concentrating on patent reform to overcome ineffective government patent regulation, and on translational genomics to actually find cures for diseases thus justifying the use of hard-earned taxpayer dollars. 


\section{References}

Cook-Deegan, R. M. 1994. Origins of the human genome project. Risk: Health,

Safety \& Environment. Vol.5. Spring. 97-118.

www.piercelaw.edu/risk/vol5/spring/cookdeeg.htm

Holman, C. 2009. Book review of Who Owns You?

http://ndpr.nd.edu/review.cfm?id=17005

Koepsell, D. 2009. Why I believe gene patenting is wrong, although it is currently legal. August 16. p. 6.

http://ieet.org/index.php/IEET/more/koepsell20090816

Whelan, M. 2006. What, if any, are the ethical obligations of the U.S. Patent

Office?: A closer look at the biological sampling of indigenous groups. Duke Law and

Technology Review. iBRIEF 0014.

Wilson, J. 2002. No patents for semantic information. The American Journal of Bioethics. 2(3):15-16. 